\title{
Effect of Subclinical Mastitis on Milk Profile Changes in Jersey Cross Bred Dairy Cows
}

\author{
N. Sri Balaji ${ }^{*}$, V. Sankar ${ }^{1}$, P. Senthilkumar ${ }^{1}$, P. Nalini ${ }^{1}$, J. Muralidharan ${ }^{1}$ \\ and A. Senthilkumar ${ }^{6}$ \\ ${ }^{1}$ Mecheri Sheep Research Station, Pottaneri-636 453, India \\ ${ }^{2}$ Farmers Training Centre, Theni-625 531, India \\ *Corresponding author
}

\begin{tabular}{l} 
K e y w o r d s \\
subclinical mastitis, \\
milk profile, Jersey \\
cross bred Cows. \\
Article Info \\
$\begin{array}{l}\text { Accepted: } \\
18 \text { April } 2020 \\
\text { Available Online: } \\
10 \text { May } 2020\end{array}$ \\
\hline
\end{tabular}

Subclinical mastitis is a major cause of economic loss in dairy herds that shows no gross inflammatory changes in udder. Often it is more prevalent than the clinical mastitis and it affects milk production and milk quality. Hence the study was undertaken to evaluate the effect of subclinical mastitis in apparently healthy 60 Jersey cross bred dairy cows in Theni District of Tamil Nadu. The mean \pm SE values of SCC levels in dairy cows with subclinical mastitis was $4.02 \pm 0.12 \times 10^{5}$ cell $/ \mathrm{ml}$ of milk and $1.24 \pm 0.21 \times 10^{5}$ cell $/ \mathrm{ml}$ of milk in case of non-infected healthy dairy cows. The mean \pm SE value of chloride content of apparently healthy non infected cows was 0.15 $\pm 0.004 \mathrm{~g} \%$ compared to the samples suspected for subclinical mastitis with chloride content of $0.21 \pm 0.006 \mathrm{~g} \mathrm{\%}$. The mean $\pm \mathrm{SE}$ value of milk $\mathrm{pH}$ in apparently healthy non infected cows was $6.51 \pm 0.04$, whereas the samples suspected for subclinical mastitis had $\mathrm{pH}$ of $7.57 \pm 0.023$, which indicated the likelihood of subclinical mastitis in Jersey cross bred dairy cows.

\section{Introduction}

Subclinical mastitis (SCM) is a major cause of economic loss in dairy herds that show no gross inflammatory changes in udder, hence remains unnoticed unless investigated by employing laboratory tests. Often it is more prevalent than the clinical mastitis, it usually precedes the clinical form, it reduces milk production, and adversely affects milk quality. Sub clinical mastitis causes colossal losses than clinical mastitis (Joshi and Gokhale, 2004).

Today mastitis stands second to Foot and Mouth Disease as a most challenging disease in high yielding dairy animals in India (Varshney and Mukherjee, 2002). Subclinical mastitis (SCM) is a major cause of economic loss in dairy herds that show no gross 
inflammatory changes in udder, hence remains unnoticed unless investigated by employing laboratory tests. Often it is more prevalent than the clinical mastitis, it usually precedes the clinical form, it reduces milk production, and adversely affects milk quality. Since there are no visible abnormalities in the milk, subclinical mastitis requires special diagnostic tests for detection.

Subclinical mastitis can be recognized indirectly by several diagnostic methods including the California mastitis test (CMT), the modified white side test, somatic cell count, $\mathrm{pH}$, and catalase tests. These tests are preferred as screening tests for subclinical mastitis as they can be used easily, yielding rapid, as well as satisfied results (Joshi and Gokhale, 2006). Somatic cell count (SCC) is the most common test to detect changes in the milk due to the inflammatory process. The greater the SCC in the milk indicates the higher the level of inflammation in the tissue. Hence, the present study was undertaken to assess the milk profile changes during subclinical mastitis in cross bred dairy Cows.

\section{Materials and Methods}

A total of 240 milk samples were randomly collected from 60 apparently healthy Jersey cross bred dairy cows in Theni District of Tamil Nadu. At the time of sample milk collection, the age of the cow, stage of lactation and health status of the mammary glands were recorded.

Aseptic procedures for collecting quarter milk samples as described by Hogan et al., (1999) were followed. During collection of milk sample, teats were washed, dried and sterilized with cotton soaked in $70 \%$ ethyl alcohol. The first 3-4 strips of milk were discarded. $15 \mathrm{ml}$ of milk were collected from each quarter into sterile vials.
The collected milk samples were immediately kept in an insulated container with ice packs and were transferred to the laboratory for somatic cell count and chemical analysis. Somatic cell count was measured microscopically by the method of Singh and Ludri (2000). Differential cell counting was also carried out to determine the presence of different cell types like lymphocyte, neutrophils, basophils, eosinophils and monocytes. The same Somatic cell count was confirmed through PortaSCC Milk Test (PortaCheck Inc, USA). The PortaSCC milk test digital reader was used to measure the SCC in simple and easy way. The kit contains all of the materials needed to perform the SCC test including digital reader, working solutions and strips. The SCC was measured as per the detailed product directions. The SCC was also verified with direct microscope to avoid error in SCC measurement.

The $\mathrm{pH}$ of the milk was estimated immediately after collection with the help of Electronic $\mathrm{pH}$ meter. The Chloride estimation were done as per BIS: SP:18 (Part XI) 1981 respectively. The data were statistically analyzed by adopting standard procedures as described by Snedecor and Cochran (1994).

\section{Results and Discussion}

The prevalence of subclinical mastitis in Jersey cross bred dairy cows of Theni District was $36.66 \%$ out of 60 Jersey dairy cows tested as shown in the Table 1. Out of 240 milk samples collected from all 4 quarters of 60 apparently healthy cows tested in this study, 61 quarters milk samples of 22 Cows showed positive results for subclinical mastitis by the CMT as shown in the Table 2 . This finding is in agreement with Tuteja et al., (1993) and they reported that the prevalence of subclinical mastitis on farms could range from 19 to $78 \%$. 
The incidence of subclinical mastitis among dairy animal might be attributed mainly to poor hygiene practices, inadequate housing and malfunctioning milking machines, improper milking procedures and inadequate treatment methods. Several research studies concluded that the contagious organisms spread during the milking process (Bray and Shearer, 1996) causing an infection of the udder as a result of entering the teat canal (Rodenburg, 1990). The mean \pm SE values of SCC levels in Jersey cross bred dairy cows with subclinical mastitis was $4.02 \pm 0.12 \mathrm{x}$
$10^{5}$ cell $/ \mathrm{ml}$ of milk and $1.24 \pm 0.21 \times 10^{5} / \mathrm{ml}$ of milk in case of non-infected healthy dairy cows. Somatic cells are always present in milk and they increase due to mammary gland infections. When udders are healthy, the somatic cell count (SCC) in milk is between 50,000 and 100,000 cells/ml (Skrzypek et al., 2004). Skrzypek et al., (2004) and Harmon (2001) reported that SCC greater than 200,000 cells $/ \mathrm{ml}$ is assumed to be a threshold distinguishing a healthy udder from a diseased udder.

Table.1 Prevalence of subclinical mastitis in Jersey cross bred dairy cows of Theni District

\begin{tabular}{|c|c|c|c|c|}
\hline Breeds of cattle & $\begin{array}{c}\text { Number of } \\
\text { tested cattle }\end{array}$ & $\begin{array}{c}\text { Number of } \\
\text { non-infected } \\
\text { cows }\end{array}$ & $\begin{array}{c}\text { Number of } \\
\text { infected } \\
\text { cows }\end{array}$ & $\begin{array}{c}\text { Prevalence rates } \\
\text { of subclinical } \\
\text { mastitis in cows }\end{array}$ \\
\hline Jersey Crossbred & 60 & 38 & 22 & $36.66 \%$ \\
\hline
\end{tabular}

Table.2 Prevalence of subclinical mastitis in examined quarter milk samples

\begin{tabular}{|c|c|c|c|}
\hline $\begin{array}{c}\text { Number of dairy } \\
\text { cows tested }\end{array}$ & $\begin{array}{c}\text { Total number of } \\
\text { milk samples }\end{array}$ & $\begin{array}{c}\text { Number of } \\
\text { positive samples }\end{array}$ & $\begin{array}{c}\text { Percentage (\%) of } \\
\text { positive samples }\end{array}$ \\
\hline $\mathbf{6 0}$ & 240 & 61 & $25.41 \%$ \\
\hline
\end{tabular}

Detection of subclinical mastitis was carried out by CMT

Table.3 Somatic cell count in non-infected and infected dairy cows

\begin{tabular}{|c|c|c|}
\hline Breeds of cattle & $\begin{array}{c}\text { SCC } * \mathbf{1 0}^{\mathbf{5}} \text { cell } / \text { ML of milk } \\
(\text { mean } \pm \text { SE) } \\
\text { in non-infected cattle }\end{array}$ & $\begin{array}{c}\text { SCC } * \mathbf{1 0}^{\mathbf{5}} \text { cell } / \text { ML of milk } \\
(\text { mean } \pm \text { SE) } \\
\text { in infected cattle }\end{array}$ \\
\hline Jersey Crossbred & $1.24 \pm 0.21 \times 10^{5}$ & $4.02 \pm 0.12 \times 10^{5 b}$ \\
\hline
\end{tabular}

The least square mean values carrying the different superscript are significantly different $(\mathrm{p}>0.05)$

Table.4 Milk pH and chloride in non-infected and infected dairy cows

\begin{tabular}{|c|c|c|c|c|}
\hline \multirow{2}{*}{ Breeds of Cattle } & \multicolumn{2}{|c|}{ Non infected cattle } & \multicolumn{2}{|c|}{ Infected cattle } \\
\cline { 2 - 6 } & $\mathbf{p H}$ & Chloride (g\%) & $\mathbf{p H}$ & Chloride (g \%) \\
\hline Jersey Crossbred & $6.51^{\mathrm{a}} \pm 0.04^{\mathrm{a}}$ & $0.15^{\mathrm{a}} \pm 0.004$ & $7.57^{\mathrm{b}} \pm 0.023$ & $0.21^{\mathrm{b}} \pm 0.006$. \\
\hline
\end{tabular}

The least square mean values carrying the different superscript are significantly different $(\mathrm{p}>0.05)$

The mean \pm SE value of milk $\mathrm{pH}$ in apparently healthy non infected cows was $6.51 \pm 0.04$, which is within the normal range of $\mathrm{pH} 6.4$ to
6.8 as reported by Vijayakumar (2003). Whereas the samples suspected for subclinical mastitis had significantly higher $\mathrm{pH}$ of $7.57 \pm$ 
0.023, which itself indicated the likelihood of subclinical mastitis.

The result of the present study indicated a relatively high prevalence of subclinical mastitis in Jersey cross bred dairy cows of the study area. Lack of maintenance of strict hygiene and poor management may be the contributory factors for subclinical mastitis. It is therefore important that farmers should adopt good management practices to prevent subclinical mastitis in dairy cows and ensure good quality of milk. The finding was communicated to the farmers of cows positive for SCC and they were asked to improve hygiene and management.

\section{References}

Bray, D. R, and J. K. Shearer. 1996. Troubleshooting a mastitis problem herd. Univ. of Florida Coop. Ext. Circular 1162. Dep. Dairy and Poultry Sci., Florida Coop. Ext. Serv., Inst. Food Agric Sci. Univ. Florida, Gainesville.

Harmon, R. J. 2001. Somatic cell counts: A primer. In: Proc. National Mastitis Council Annual Meeting. pp. 3-9.

Hogan, J. S., R. N. Gonzalez, R. J. Harmon, S. C. Nickerson, S. P. Oliver, J. W. Pankey, and K. L. Smith. 1999. Laboratory Handbook on Bovine Mastitis. Madison, WI: National Mastitis Council.

IS (Indian Standard). 1981. IS: SP 18, Part XI, Dairy Products, Bureau of Indian Standards (BIS), Manak Bhavan, New Delhi.

Joshi, S and Gokhale, S. (2004). Status of mastitis as an emerging disease in improved and periurban dairy farms in India. 23rd World Buiatrics Congress Quebec city, Canada.
Joshi, S. and S. Gokhale (2006). Status of mastitis as an emerging disease in improved and periurban dairy farms in India. BAIF Development Research Foundation and Research Station, Uruli Kanchan, Pune, Maharashtra. Ann. N. Y. Acad. Sci., 1081: 74-83.

Rodenburg, J. (1990): Mastitis prevention: Environmental control: Ontario. Ministryof Health. Food Animal Production Medicine. W. B. Saunders Company, Pennsylvania, USA.

Schalm, O.W. et al., (1971). Bovine Mastitis. Lea and Febiger, Philadelphia. pp. 102-103.

Singh, M and R.S. Ludri (2001). Somatic cell counts in Murrah buffaloes during different stages of lactation, parity and season. Asian-Australasian Journal of Animal Sciences, 41(2) : 189-192.

Skrzypek, R., Wtowski, J., Fahr, R.D.: Factors affecting somatic cell count in cow bulk tank milk - a case study from Poland. J. Vet. Med. A, Physiol. Pathol. Clin. Med., 2004.

Snedecor, G.W. and W. G. Cochran, 1994 Statistical methods. 8 edition. Iowa State University Press, Ames, Iowa.

Tuteja, F.C., Kapur, M.P., Sharma, A. and Vinajaka, A.K. (1993). Studies on bovine subclinical mastitis: Prevalence and microflora. Indian Vet. J., 70: 787-791

Varshney, J.P. and Mukherjee, R. 2002. Recent advances in management of bovine mastitis. Intas Polivet 3(1): 62-65.

Vijayakumar, K, (2003). Tests for detection of mastitis. In: Proceeding Indian Veterinary Congress X Annual $4^{\text {th }}$ Round Table on mastitis 14-15 April, College of Veterinary Science and Animal Husbandry, C.S.K.H.P.K.V, Palampur (H.P.). Pp. 137145 .

\section{How to cite this article:}

Sri Balaji, N., V. Sankar, P. Senthilkumar, P. Nalini, J. Muralidharan and Senthilkumar, A. 2020. Effect of Subclinical Mastitis on Milk Profile Changes in Jersey Cross Bred Dairy Cows. Int.J.Curr.Microbiol.App.Sci. 9(05): 2423-2426. doi: https://doi.org/10.20546/ijcmas.2020.905.276 